\title{
"Breast milk is important": what do nursing mothers in Fortaleza think about breastfeeding?
}

Lorena Oliveira Peixoto 1

https://orcid.org/0000-0002-7196-5868

Daniela Vasconcelos de Azevedo 2

iD https://orcid.org/0000-0003-2789-7471

Leontina Fernandes Britto 3

https://orcid.org/0000-0001-6083-5075

Isadora Nogueira Vasconcelos 4

https://orcid.org/0000-0002-6608-2112

\begin{abstract}
1,2,4 Centro de Ciências da Saúde. Universidade Estadual do Ceará. Av. Dr. Silas Munguba, 1700. Itaperi. Fortaleza, CE, Brasil. CEP: 60741-000. E-mail: lorena_lop@hotmail.com
\end{abstract}

3 Hospital Distrital Gonzaga Mota de Messejana. Fortaleza, CE, Brasil.

\begin{abstract}
Objectives: to analyze the meaning of breastfeeding for nursing mothers, users of the public health network in Fortaleza city, Ceará.

Methods: a cross-sectional study was carried out with nursing mothers from nine health units. The data were collected through the application of a socioeconomic and health questionnaire and the Word Free Association Test, using "breastfeeding" as an induced stimulus. The terms referred to in the Word Free Association Test were grouped into categories and analyzed by the EVOC $2000 \circledR$ software, which showed the results in a four-cell table, where the categories were distributed according to the level of meaning to the mothers.

Results: the sample consisted of 279 nursing mothers. More than $60 \%$ of these women referred in receiving guidance on breastfeeding in prenatal, puerperal and childcare consultations, and $68 \%$ of them reported having no difficulties in breastfeeding. The most significant categories identified by the Word Free Association Test were: Milk, Important, Health, and Love.

Conclusions: for the nursing mothers, breastfeeding is an important practice, represented by the breast milk itself, which is permeated by positive meanings. Knowing these meanings helps to understand the factors associated to early weaning, making it possible to reconstruct care directed to this public.
\end{abstract}

Key words Breastfeeding, Mother-Child Relationships, Children's Health 


\section{Introduction}

Breastfeeding (BF) is the most natural and economical way of promoting infant nutrition ${ }^{1}$ and is positively related to infant's health ${ }^{2,3}$ and the reduction of infant mortality. ${ }^{4}$ Breastfeeding also generates benefits to maternal health, contributing to reduce the onset of certain cancers, chronic noncommunicable diseases, and postpartum depression. $5-7$

The World Health Organization (WHO) recommends breastfeeding should be started in the first hour of the baby's life and maintained as exclusive food for the infant for the first six months, and then supplemented from six months to two years of age or more. 8

Data from the latest national survey on prevalence of BF in 2008 showed that $67.7 \%$ of newborns in Brazil had been breastfed in the first hour of life. However, they indicated a significant drop in the probability of children being exclusively breastfed (EBF) in the first days of life in all the regions in Brazil, especially in the Northeast, where a probability of interruption of EBF was found to be approximately $40 \%$. The median duration of EBF was 54.1 days (1.8 months) in the Brazilian capitals and 34.9 days (1.2 months) in the Northeast. ${ }^{9}$ These data demonstrate that, although women start EBF, they abandon the practice too early.

Breastfeeding is not only determined by the biological ability of the mother to produce the ideal food for her child, but also by the social, cultural, economic and historical context in which the woman is inserted.10-12 Thus, some determinants, such as low schooling and lack of maternal guidance, absence of the father, mother working, maternal choice not to breastfeed, and postpartum depression are related to early weaning. ${ }^{13-16}$

Studies carried out by Carrascoza et al. 17 and Moreira et al. ${ }^{11}$ pointed out that $\mathrm{BF}$ promotes both positive and negative feelings in nursing mothers. Although BF represents a challenge, mothers who breastfed expressed feelings of pleasure, satisfaction, and fulfillment as mothers. However, nervousness, pain and sadness may also be part of the experience of some women.

Considering that in the Brazilian context mothers stop EBF precociously, it is essential to know their perception about breastfeeding, in order to try to understand the reasons that lead them to abandon this practice. This study aims to analyze the meanings that breastfeeding has for nursing mothers, users of the public health network in Fortaleza city, Ceará.

\section{Methods}

This is a cross-sectional study with a quantitative approach conducted in Fortaleza city with the goal of analyzing the maternal and child healthcare network in Fortaleza. This study was conducted between 2014 and 2016.

Nine Unidades de Atenção Primária à Saúde (UAPS) (Primary Health Care Units) were chosen among the six Secretarias Executivas Regionais do Municipio (SERs) (Regional Executive Secretaries of the Municipality) from October 2014 to October 2015. Such collection period differs from a larger research because it is just a part of it and refers only to the interviews with the nursing mothers.

The study used a convenience sample of nursing mothers who attended child care consultations during the study period. The inclusion criteria were: age $\geq 18$ years old, have a child under two years old, and registered at the health unit. The data were collected through a socioeconomic and health questionnaire and through the application of the Teste de Associação Livre de Palavras (TALP) (Word Free Association Test) applied by undergraduate and master's students in nutrition who had been previously trained. The nursing mothers were invited to participate in the research while they were waiting for their children's consultation. The maternal variables collected were age, schooling, marital status, having an outside job, and information about $\mathrm{BF}$ (EBF in children under six months of age, guidelines on breastfeeding received by mothers, and the difficulties in practicing $\mathrm{BF}$ ).

The TALP was used as a theoretical contribution to the knowledge of meanings that breastfeeding has for the women who are practicing it. The TALP is a projective test that it is possible to capture mental projections spontaneously, quickly and objectively, and reveals the implicit and latent contents that represent a certain phenomenon to be studied. 18 In its application, the interviewee is asked to externalize in a written or spoken manner words or expressions that immediately come to mind when in contact with a certain inductive, visual or auditory stimulus. 18,19

In this study, the test was applied individually and the mothers were instructed to tell the first three words that came to mind when they heard the inducing stimulus "breastfeeding". In order to eliminate possible doubts about the use of the TALP and to ensure its comprehension, the mothers were previously instructed with an example used as inducing stimulus, a word unrelated to the theme. 
Based on the evoked terms, graphical accents, articles, verbs and connecting words were eliminated, and only the nucleus that gave meaning to what the participants said was kept. In this way, a dictionary of words was created, respecting the order of evocation of words: first, second and third places. Then, these terms were used to create categories in grouping words with identical, similar or close semantic meaning. Each category was named according to the word contained in it that presented greater frequency of evocation. 18

After this step, the dictionary was saved as a "comma-separated" option, using an Excel ${ }^{\circledR}$ spreadsheet, to be transported to the EVOC $2000^{\circledR}$ program. This software analyzes data considering the average frequency and the average order of evocation. The average frequency refers to the number of times the word was evoked and is obtained by dividing the total number of words by the number of categories. The average order of evocations takes into consideration the order in which each word was evoked in first, second, or third place, and is provided by the software itself.

In order to present the meanings that the "breastfeeding" phenomenon has for these participants, we chose to use a four-cell table created by the EVOC $200{ }^{\circledR}$ software, in which the categories are distributed according to the largest and smallest degree of meaning they have for the group studied. Figure 1 shows a graphical representation of how the software classifies the categories.

Regarding to the four-cell table, it can be interpreted as follows: the upper left quadrant shows the categories that had high frequency and low order of evocation; they are the categories with greater significance for the group studied. In the upper right quadrant are placed the categories of the first periphery, with high frequency and higher than average order of evocation; because of their high frequency, they are also significant. At the lower left quadrant are the contrast categories, which have low frequency and lower than average order of evocation; they are representative for a small group of participants. These words can reinforce the ones of the first periphery. In the last quadrant, the categories of the second periphery are placed with less frequency and order of evocation above the average, which gives them less terms of significance to the group. 19

The analysis of the results was based on the categories formed by the evoked words, and supported on specialized literature on the subject. Tables and figures were used to allow a better visualization of the results.

The present study was approved by the Research Ethics Committee of the Universidade Estadual do Ceará, following a Resolution n. 466/12 of the National Health Council, under the document 388.016 and CAEE 14911313.0.0000.5534.

Figure 1

Four-cell table.

Categories of greater significance for the interviewees
$\begin{aligned} & \text { Are those that have frequency } \geq \mathrm{Fr} * \text { and order of evocation } \\ & \angle \mathrm{AOE} * *\end{aligned}$
$\begin{aligned} & \text { Categories that were significant for a small number of } \\ & \text { interviewees }\end{aligned}$
Are those that have frequency $<\mathrm{Fr}$ and order of evocation
$<\mathrm{AOE}$

$$
\begin{aligned}
& \text { Categories of great significance for the interviewees } \\
& \text { Are those that have frequency } \geq \mathrm{Fr} \text { and order of evocation } \\
& \geq \mathrm{AOE}
\end{aligned}
$$

\footnotetext{
* Average Evocation Frequency; ** Average Order of Evocation
}

Source: Adapted from Oliveira et al. 18 


\section{Results}

On average, 560 children under two years of age are assisted monthly in childcare clinics at the nine health units. Until the end of the collection period, it was possible to interview 279 nursing mothers; it was not possible to conduct interviews in some of the days they were scheduled for childcare consultations. There was no refusal on behalf of the women who were approached to participate in the research.

The nursing mothers had a median age of 26 , ranging from 18 to 45 years old. The majority had a partner $(73.7 \%)$, had graduated from high school (65.8\%), and did not have an outside job (71.8\%) (Table 1).

In relation to the children, $115(41.2 \%)$ were under six months of age, $66(57.4 \%)$ were exclusively breastfed; among the latter, $44(66.7 \%)$ were less than three months old (Table 1).

More than half of the mothers had received guidance about BF; among them, 193 (69.7\%) received the instructions during prenatal care, $190(68.8 \%)$ in the puerperium, and $167(61.6 \%)$ during childcare consultations. Most of the mothers $(68.0 \%)$ reported not having any difficulties in breastfeeding their babies (Table 1).

The analysis of the TALP showed 656 terms evoked in which 209 were different from each other. The mean order of evocation was 1.8 and the mean frequency was 65.6. (Figure 2)

In the upper left quadrant of the four-cell table, the categories were important and milk, considered as the most significant for these women. In the upper right quadrant, the categories were health and love, which were the most relevant peripheral elements. In the lower left quadrant, the category good emerged, which was significant for a small number of the interviewees. In the lower right quadrant were placed the categories that least represented the group and that formed child, pain, juice, don't know and care.

The category milk had high frequency and lower order of evocation, being the most representative. In this category, the gathered words such as breastfeeding, breast milk, and breast. Then, important, constituted by the terms such as essential, necessary and fundamental, had low order of evocation and high frequency, but lower than the previous category.

Health and love presented high frequencies, but since their evocation orders were also high, they had a lower or more peripheral significance. The first was formed by the terms healthy, health-child, avoid-disease, nutritious, and the second was formed by affection, pleasure, satisfaction, and among others.
For a small number of interviewees, the act of breastfeeding had the meaning of being good. Some women demonstrated indifference or were not able to express their feelings about breastfeeding, as in the category don't know. Another small group of women attributed a negative connotation to $\mathrm{BF}$, which can be found in the category pain from words such as much-pain, discomfort, and swelling. The categories child, care, and juice were also insignificant for the study group participants.

\section{Discussion}

Breastfeeding was considered an important practice and it was represented by its own product, that is, breast milk, by the nursing mothers in this present study. Breastfeeding was also highlighted as a source of health and an expression of love.

As verified in the category milk, the element that emerged among the interviewees about the act of breastfeeding was the food physiologically produced by them to feed their children. Corroborating with the findings in this present study, Carrascoza et al. 17 while searching to characterize and analyze the mothers' perception in the act of breastfeeding, found references to breast milk throughout the discourses of some women about breastfeeding. This finding reveals the intrinsic relationship between breastfeeding and the milk produced by them.

During the pregnant-puerperal cycle, women use to mentalize the experience of offering breast milk to their children, 20 which may also justify the presence of such element in their unconsciousness during this period.

In the category important, the interviewees emphasize the indispensability of breastfeeding and its relation to the children's growth and development. In the category health, the mothers' knowledge about the protective effect of breast milk and the nutritional value of this food was evident. These findings are in agreement with what was found by Eulálio et al. ${ }^{21}$, who observed the perception that breast milk promotes healthy growth and development of the infants, in the interviewees' speech. This result evidences the incorporation, by the mothers, of the technical-scientific discourse used both in the BF campaigns and in the assistance given by health professionals to the nursing mothers. ${ }^{22}$

The women in the present study did not seemed to be aware of the benefits that breastfeeding brings for themselves, since the meanings evoked in the TALP only demonstrated benefits for the children. This result differs from Rocha et al. 23 found in a study conducted with pregnant women followed up in public prenatal care programs in cities from the 


\section{Table 1}

Sociodemographic characteristics and information about breastfeeding from nursing mothers in primary care. Fortaleza, 2014-2015.

\begin{tabular}{|c|c|c|}
\hline \multirow{2}{*}{ Characteristics } & \multicolumn{2}{|c|}{ Characteristic distribution $\mathrm{N}=\mathbf{2 7 9}$} \\
\hline & $\mathrm{n}$ & $\%$ \\
\hline \multicolumn{3}{|l|}{ Age } \\
\hline $18-23$ & 100 & 35.8 \\
\hline $24-29$ & 84 & 30.1 \\
\hline $30-35$ & 56 & 20.1 \\
\hline$>35$ & 39 & 14.0 \\
\hline \multicolumn{3}{|l|}{ Marital status } \\
\hline With partner & 205 & 73.7 \\
\hline Without partner & 73 & 26.3 \\
\hline \multicolumn{3}{|l|}{ Schooling } \\
\hline Elementary School & 95 & 34.2 \\
\hline High school & 170 & 61.1 \\
\hline Higher education & 13 & 4.7 \\
\hline \multicolumn{3}{|l|}{ Have an outside job } \\
\hline Yes & 78 & 28.2 \\
\hline No & 199 & 71.8 \\
\hline \multicolumn{3}{|c|}{ EBF situation for children under six months of age } \\
\hline$<3$ months & 44 & 66.7 \\
\hline$\geq 3$ months & 22 & 33.3 \\
\hline \multicolumn{3}{|c|}{ Difficulties to breastfeed } \\
\hline Yes & 89 & 32.0 \\
\hline No & 189 & 68.0 \\
\hline \multicolumn{3}{|l|}{ Guidance on BF: } \\
\hline \multicolumn{3}{|l|}{ During prenatal care } \\
\hline Yes & 193 & 69.7 \\
\hline No & 84 & 30.3 \\
\hline \multicolumn{3}{|l|}{ In the puerperium } \\
\hline Yes & 190 & 68.8 \\
\hline No & 86 & 31.2 \\
\hline \multicolumn{3}{|c|}{ At childcare consultations } \\
\hline Yes & 167 & 61.6 \\
\hline No & 104 & 38.4 \\
\hline
\end{tabular}

Marital status, schooling and difficulties to breastfeed $n=278$; Have an outside job and guidance on $B F$ during prenatal care $n=277$; Guidance on $B F$ in the puerperium $n=276$; Guidance on $B F$ in childcare consultations $n=271$; $E B F$ situation for children under six months $n=66$. 
Figure 2

Meanings of breastfeeding for nursing mothers in primary care. Fortaleza, 2014-2015.

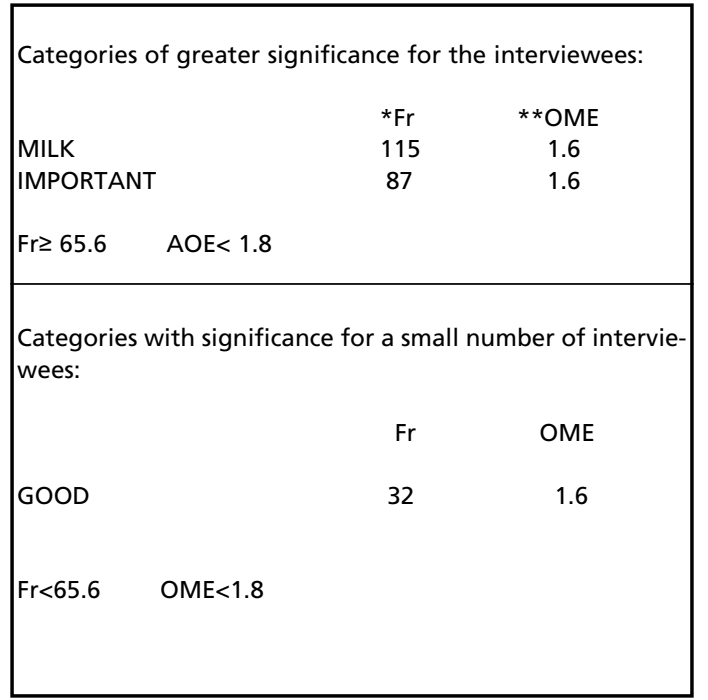

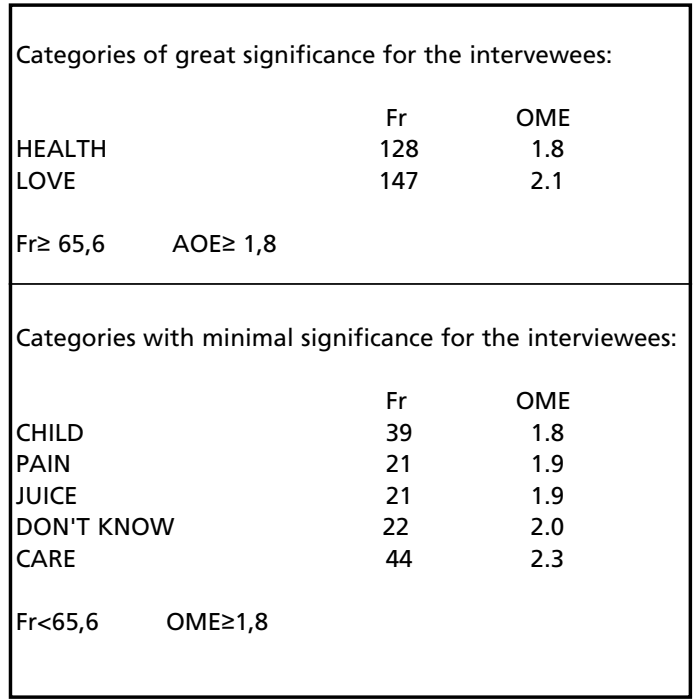

* Average Frequency of Evocation; ** Average Order of Evocation.

state of São Paulo, which showed that maternal representations about breastfeeding was focused on maternal love, the protection provided by breast milk to the baby, and its benefits for the mother.

These results demonstrate that campaigns and actions on breastfeeding promote only issues related to the baby's health while those related to maternal health are neglected.24 Thus, the absence of the women's perception on the benefits of breastfeeding for their own health points out the need of health professionals to inform them about these advantages during individual consultations and educational activities, in order to increase the mothers' motivation for the practice of EBF.

The category love revealed positive maternal feelings about the practice of breastfeeding and the profile of zealous mothers who care, love and protect their children. Although this category did not represent the major meaning of breastfeeding for the nursing mothers studied, these results were similar to those found by Rocha et al.23 and Carrascoza et al. ${ }^{17}$, who showed the relevance of maternal love for the practice of breastfeeding.

The contact of the mother's breast with the baby's face establishes a bond between the mother and the child, a way for the women to feel once again the bond between her body and of the child. 25 In Caceido et al. 26 study, this was the main reason for the mothers to consider breastfeeding as an act of love.

Moreira et al. 11 carried out a study on the social representation of breastfeeding in three generations of women in the same family, and showed that the experiences in BF were portrayed with feelings of pleasure, fulfillment and joy, although negative feelings such as nervousness, pain and sadness, were also cited. This result reveals that breastfeeding can generate ambiguous maternal feelings, which are determined by each woman's experiences.

In the present study, negative feelings were restricted to a few women, and the category pain was the least significant. The same result was found in a study on the social representation of women who interrupted EBF too early, which had three categories, and one of them that contemplated negative feelings was the least relevant. ${ }^{27}$ Regarding to negative feelings, it was observed that the suffering during breastfeeding was related to breast problems, such as breast engorgement and nipple fissures. This result corroborates to other studies that show pain as a factor that interferes with the maintenance of breastfeeding. 10 The nursing mothers' lack of preparedness before the physical challenges posed by $\mathrm{BF} 28$ also negatively affects the mothers' decision to continue breastfeeding. Therefore, early approach of the correct technique in breastfeeding and provi- 
sions of supporting women more with the act of active listening is necessary to achieve a successful breastfeeding, to identify the situation of breastfeeding and to work with individualized counseling. ${ }^{14,27}$

As a limitation of this study, we must mention some peculiarities of the TALP method for collecting and analyzing data, because it is not a usual research method. It was observed that the participants had difficulties to verbalize the first three words or expressions that came to mind when listening to the induced stimulus. Consequently, the number of words in the dictionary giving rise to the categories was reduced. By using frequency and average order of evocation, a greater number of words would help in the construction of the categories. Furthermore, some interviewees did not readily verbalize what came to mind, which may have interfered with the research outcome. In order to minimize such issues, before the implementation of the TALP, an explanation had to be made about the method and an example should have been given to each interviewee.

This study led to the conclusion that the meanings attributed by the mothers on breastfeeding were predominantly positive, possibly due to the guidelines on $\mathrm{BF}$ received during prenatal, puerperal and childcare consultations. However, it is worth noting that a little more than half of the children under six months of age were on EBF and most of them were less than three months old, showing that although the mothers had information that would favor the maintenance of EBF, but they did not continue to practice it. Early discontinuation of EBF by a significant portion of the population was also observed in the II Pesquisa de Prevalência de Aleitamento Materno nas Capitais Brasileiras e Distrito Federal (II Survey on Prevalence of Maternal Breastfeeding in Brazilian Capitals and the Federal District), whose median time on EBF was 1.8 months in Brazil. ${ }^{9}$ Therefore, health professionals should seek in identifying other factors that may be related to such abandonment. Despite this, the positive meanings of breastfeeding in view of the participants in the study constitute of a favorable result to increase EBF rates at a local level, since the interviewees judged EBF to be essential and demonstrated to have assimilated the information transmitted by health workers about it.

The nursing mothers considered breastfeeding an important practice, represented by breast milk, which promotes health to the baby and expresses an act of love. For them, BF is permeated with positive meanings.

Although the results found here are applicable only to the group studied, knowing the meanings that breastfeeding has for the nursing mothers in helping to understand the factors associated to early weaning, making it possible to restructure the care directed to this public. During health consultations and educational activities carried out with the nursing mothers, it is essential to investigate their feelings about the practice of breastfeeding, as well as the social and cultural context in which they are inserted in.

Considering that $\mathrm{BF}$ generates positive and sometimes negative feelings, it is necessary to provide more support for women throughout their pregnancy and after childbirth. It is important not only that they receive guidance, but also that they feel encouraged and listened to, for the clarification of doubts and provision of help when facing their difficulties.

\section{Authors' contributions}

Peixoto LO - Data analysis and writing of the manuscript. Azevedo DV - Project design and data analysis. Britto LF - Data collection, writing and revision of the manuscript. Vasconcelos IN - Data collection, writing and revision of the manuscript.. All authors approved the final version of the manuscript.

\section{References}

1. Brahm P, Valdés V. Beneficios de la lactancia materna y riesgos de no amamantar. Rev Chil Pediatr. 2017; 88 (1): 714.

2. Santos FS, Santos LH, Saldan PC, Santos FCS, Leite AM, Mello DF. Aleitamento materno e diarreia aguda entre crianças cadastradas na estratégia saúde da família. Texto Contexto Enferm. 2016; 25 (1): e0220015.
3. Tromp I, Jong JK, Raat H, Jaddoe V, Franco O, Hofman A, Jongste J, Moll H. Breastfeeding and the risk of respiratory tract infections after infancy: The Generation R Study. PLoS One. 2017; 12 (2): e0172763.

4. Boccolini CS, Carvalho ML, Oliveira MIC, PérezEscamilla R. Breastfeeding during the first hour of life and neonatal mortality. J Pediatr (Rio J). 2013; 89 (2): 131-6. 
5. Jäger S, Jacobs S, Kröger J, Fritsche A, Schienkiewitz A, Rubin D, Boeing H, Schulze MB. Breast-feeding and maternal risk of type 2 diabetes: a prospective study and meta-analysis. Diabetologia. 2014; 57 (7): 1355-65.

6. Dois AC, Lucchini CR, Villarroel LD, Uribe CT. Efecto del contacto piel con piel sobre la presencia de síntomas depresivos post parto en mujeres de bajo riesgo obstétrico. Rev Soc Bol Ped. 2015; 54 (2): 102-9.

7. Joukar F, Ahmadnia Z, Atrkar-Roushan Z, Hasavari F, Rahimi A. The Investigation of Risk Factors Impacting Breast Cancer in Guilan Province. Asian Pac J Cancer Prev. 2016; 17 (10): 4623-9.

8. WHO (World Health Organization). Complementary feeding: report of the global consultation, and summary of guiding principles for complementary feeding of the breastfed child. Geneva, Switzerland: World Health Organization; 2001.

9. Brasil. Ministério da Saúde. II Pesquisa de Prevalência de Aleitamento Materno nas Capitais Brasileiras e Distrito Federal. Brasília, DF; 2009

10. Junges CF, Ressel LB, Budó MLD, Padoin SMM, Hoffman IZ, Sehnem GD. Percepções de puérperas quanto aos fatores que influenciam o aleitamento materno. Rev Gaúcha Enferm. 2010; 31 (2): 343-50.

11. Moreira MA, Nascimento ER, Paiva MS. Representações sociais de mulheres de três gerações sobre práticas de amamentação. Texto Contexto Enferm. 2013; 22 (2): 43241.

12. Angelo BHB, Pontes CM, Leal LP, Gomes MS, Silva TA, Vasconcelos MGL. Práticas de apoio das avós à amamentação: revisão integrativa. Rev Bras Saúde Mater Infant 2015; 15 (2): 161-70.

13. Machado MCM, Assis KF, Oliveira FCC, Ribeiro AQ, Araújo RMA, Cury AF, Priore SE, Franceschini SCC. Determinantes do abandono do aleitamento materno exclusivo: fatores psicossociais. Rev Saúde Pública. 2014; 48 (6): $985-94$

14. Vieira TO, Vieira GO, Oliveira NF, Mendes CMC, Giugliani ER, Silva LR. Duration of exclusive breastfeeding in a Brazilian population: new determinants in a cohort study. BMC Pregnancy Childbirth. 2014; 14 (175): $1-9$.

15. Radzyminski S, Callister LC. Mother's Beliefs, Attitudes, and Decision Making Related to Infant Feeding Choices. J Perinat Educ. 2016; 25 (1): 18-28.

16. Silva CS, Lima MC, Sequeira-de-Andrade LA, Oliveira JS Monteiro JS, Lima NM, Santos RM, Lira PI. Association between postpartum depression and the practice of exclu- sive breastfeeding in the first three months of life. J Pediatr (Rio J). 2017; 93 (4): 356-64.

17. Carrascoza KC, Possobon RF, Costa-Júnior AL, Moraes BAM. Aleitamento materno em crianças até os seis meses de vida: percepção das mães. Physis. 2011; 21 (3): 104560 .

18. Oliveira DC, Marques SC, Gomes AM, Teixeira MC. A análise das evocações livres: uma técnica de análise estrutural das representações sociais. In: Moreira ASP, Camargo BV, Jesuíno JC, Nóbrega SM. Perspectivas teóricometodológicas em representações sociais. João Pessoa: Universitária; 2005. p.573-99.

19. Sá CP. Núcleo Central das Representações Sociais. Petrópolis: Vozes; 1996. p.99-138.

20. Leite GO, Martins FDP, França MS, Ângelo BHB, Vasconcelos MGL, Pontes CM. Representações sociais de mulheres sobre o cheiro do leite materno. Esc Anna Nery. 2016; 20 (4): e20160090.

21. Eulalio MC, Macedo JQ, Gomes LN, Goes FSN. Significado da amamentação vivenciado por mães nutrizes. Rev Enferm UFSM. 2014; 4 (2): 350-8

22. Javorski M, Caetano LC, Vasconcelos MGL, Leite AM, Scochi CGS. As representações sociais do aleitamento materno para mães de prematuros em unidade de cuidado canguru. Rev. Latino-Am Enfermagem. 2004; 12 (6): 8908.

23. Rocha NB, Garbin AJI, Garbin CAS, Moimaz SAS. O ato de amamentar: um estudo qualitativo. Physis. 2010; 20 (4): 1293-305.

24. Azevedo DS, Reis ACS, Freitas LV, Costa PB, Pinheiro PNC, Damasceno AKC. Conhecimento de primíparas sobre os benefícios do aleitamento materno. Rev Rene Fortaleza. 2010; 11 (2): 53-62.

25. Rosa R, Martins FE, Gasperi BL, Monticelli M, Siebert ERC, Martins NM. Mãe e filho: os primeiros laços de aproximação. Esc Anna Nery. 2010; 14 (1): 105-12.

26. Caicedo NS, Carrillo M, Gómez JG. Breastfeeding Education: disagreement of meanings. Invest Educ Enferm. 2016; 34 (2): 396-404.

27. Osório CM, Queiroz ABZ. Representações sociais de mulheres sobre a amamentação: teste de associação livre de idéias acerca da interrupção precoce do aleitamento materno exclusivo. Esc Anna Nery R Enferm. 2007; 11 (2): 261-7.

28. Charlick SJ, McKellar L, Gordon AL, Pincombe J. The private journey: An interpretative phenomenological analysis of exclusive breastfeeding. Women Birth. 2018; 32 (1): e34-e42.

Received on December 16, 2017

Final version presented on October 23, 2018

Approved on January 23, 2019 